\title{
A posthuman perspective on early literacy: $A$ literature review
}

\author{
Zhen Lin', Guofang Li $^{2}$
}

\begin{abstract}
Drawing on research about young children's literacy development, this review article discusses a recent paradigmatic turn for understanding the child and childhood from human-centerism to posthumanism. Building on the new materialist tradition (e.g., Barad, 2007) and the assemblage theory of Deleuze and Guattari (1987, 1997), the posthuman lens enables researchers and educators to see children as parts of entangled networks of relationships who continuously intra-act with their peers, teachers, materials, and the other nonhuman entities and activities produced constantly by the child-material entanglements. As such, the posthumanist perspective expands the current research on early literacy by offering new possibilities for re-conceptualizing the child, the materials or resources for early literacy, and the meaning of childhood and children's play. These new ways of seeing the child, the materials, and childhood have also generated new pedagogical practices that are material-oriented, intra-active, and flexible. The review concludes by providing directions for conducting research from a posthuman perspective in the field of early literacy education.
\end{abstract}

\section{Article History}

Received: 01 November 2020

Accepted: 18 December 2020

\section{Keywords}

Early literacy;

Posthumanism; Materials;

Nonhuman entities; Child

and childhood

\section{Introduction}

Over the past few decades, there have been continuing inter-disciplinary shifts and reconceptualizations regarding how researchers and educators approach early literacy and language learning. One recent advancement examines the multimodal nature of early literacy development, seeing early literacy practices as involving multiple symbolic systems in real-world contexts (e.g., Jewitt, 2011; Kress, 1997, 2011). While early language is viewed as playing a fundamental role in young children's meaning-making, multiple modes of children's representations and the myriad materials within the different sociocultural contexts also impact their early meaning-making (e.g., Dobinson \& Dunworth, 2019; Hill, 2020; Narey, 2017). Children's multimodal interactions with differential materials (such as making pillows as cars or playing with the cardboard box as a pirate ship) are seen as "communications" through which children strategically choose and use actions, materials, and artifacts for a communicative purpose (Kress, 1997, p. 9).

The multimodal perspective expands the common assumptions that emphasize the nature of early literacy practices as human endeavours and lies on what children do "with each other" and "to materials" to learn to communicate (Kuby \& Crawford, 2018, p. 21), whereas the posthuman perspective moves beyond the multimodal perspective and prioritizes children's ways of doing/knowing/being literacies and their unexpected and emergent literacy practices with materials and other nonhuman entities (e.g., Hackett \& Rautio, 2019; Hackett \& Somerville, 2017; Kuby, Spector, \& Thiel, 2019). Researchers, therefore, note that this posthuman lens foregrounds the agency of nonhumans (e.g., materials, animals, and contexts) and humans (children) in co-constructing meanings; they also believe that the lens enables them to theorize and

\footnotetext{
${ }^{1}$ The University of British Columbia, Faculty of Education, Language and Literacy Education, Vancouver, Canada, e-mail: zhen.lin@alumni.ubc.ca, ORCID: https://orcid.org/0000-0001-7790-1630

${ }^{2}$ The University of British Columbia, Faculty of Education, Language and Literacy Education, Vancouver, Canada, e-mail: guofang.li@ubc.ca, ORCID: https://orcid.org/00000002-5523-6892
} 
examine materials as active agents in producing discourses and realities, further disturbing the humannonhuman or natural-cultural boundaries.

From human-centered research to posthumanism, the paradigm shift enables productive potentials for researchers and educators to rethink and reinterpret early literacy as emergent, entangled, and embodied (e.g., Enriquez, 2016; Leander \& Boldt, 2013). It adds to what counts as literacy by focusing more on the process of making meaning than just meaning. The current article reviews this emerging trend of studies targeting early literacy development from this posthuman lens. This review was guided by the following questions:

1. How do researchers employ posthuman theories to frame their exploration of young children's early literacy development?

2. What are the new understandings of early literacy provided by the posthuman perspective, and what are the pedagogical implications?

3. What are the implications for future research and practice?

Through responding to the three guiding questions, this review aims to uncover alternative interpretations of early literacy, the child, and the childhood from the posthuman lens in different contexts. It also seeks to provide a snapshot of how posthumanist theories influence early literacy educators in fostering early literacy development in their classrooms and beyond. Further, this review will also shed light on the gaps in the conventional literature on early literacy research that can be better addressed through a posthuman lens.

\section{Posthumanism in early literacy: An overview of key concepts and approaches}

While there is a variety of scholarship to interpret posthumanism, two main approaches have been taken in the field of early education: agential realism in the new materialist tradition (e.g., Barad, 2007; Coole \& Frost, 2010) and the assemblage theory of Deleuze and Guattari $(1987,1997)$.

New materialism asserts that all human and nonhuman entities in the world are matters and that knowledge and phenomenon emerge from the continuous and various encounters among living and nonliving entities (e.g., Barad, 2007; Bogost, 2012; Braidotti, 2013; Žižek, 2014). Sanzo (2018) validates that new materialism has been coined as early as the 1990s as "a theoretical turn away from the persistent dualism in modern and humanist traditions whose influences are present in much of cultural theory" (n. p.). One key approach within new materialism was taken up in early literacy research was Barad's (2007) agential realism. Building on the "quantum ontology" that emphasizes connectivity and relationality of different entities in the world, the concept of agential realism further sees the world as comprised of phenomena or objects that are products of "the ontological inseparability/entanglement of intra-acting agencies" (p. 139). In a phenomenon, actants including human and nonhuman objects do not pre-exist but come into being through their entanglements with material beings in the more-than-human world, namely, intra-actions, that change "possibilities for worldly reconfiguring" (Barad, 2012, interviewed by Dolphijn \& van der Tuin, p. 55). To Barad, agency is "no longer aligned with human intentionality or subjectivity" (p. 177) through which human do things "to make changes in the world" (Thiel, Kuby, \& Spector, 2019, p. 19) but "a matter of intra-acting" or "an enactment" (p. 178) that generates practices of mattering or meaning making from intra-actions of humans, nonhumans, and the more-than-human world in the material-discursive conditions.

In early literacy, agential realism offers a paradigmatic shift from the humanist assumption of the relationship between active minds and passive objects to the active agential roles of both children and materials playing together in the dynamic becoming of knowledge and relationships. The shift of ontological focus motivates the scholarship to ask how languages and literacies come to be and to re-read children's literacy events posthumanly by 'trying to do justice to the materials" (Jokinen \& Murris, 2020, p. 49) that children work with during the becoming of literacies and considering the power of things enacted in the interactions between materialized children bodies and materials. 
A posthuman perspective on early literacy...

Another theoretical take-up in early education from a posthuman perspective is the re-reading of the assemblage theory proposed by Deleuze and Guattari in their book, A Thousand Plataeus (1987). Assemblage theory explores the way heterogeneous elements or assemblage components in material systems select, compose, and self-organize to articulate meaning. Building on Deleuze and Guattari, Bennett (2010) rereads the concept of "assemblage" as the "ad hoc groupings of diverse elements" (pp. 23-24) in a phenomenon in which "no one materiality or type of material has sufficient competence to determine consistently the trajectory or impact of the group" (p. 21). Bennett argues that the lively kind of agency of nonhuman objects, namely, "thing power", manifests through the forming processes of the humannonhuman assemblages.

Moreover, another take-up of the assemblage theory in early literacy research is the interpretation of affects and components within and among other bodies in order to better understand the child from a posthuman perspective. In this regard, scholars align and re-conceptualize from a posthuman perspective several terms suggested by Deleuze and Guattari, including affect (1987) and desire (1997), in order to seek new insights on young children's literacy development. A Deleuzoguattarian explanation of affect is nonconscious, instinctive bodily experiences (1987). In a posthuman reading, affect serves as a means to understand the "non-cognitive, non-volitional expressions of life, including feelings, animation, tactility, and habituation" (Roelvink \& Zolkos, 2015, p. 1). The affective approach thus scaffolds early literacy researchers to explore the complex interrelations of children's bodies, thing powers, contextual-situated emotions, and material-discursive practices in a specific time and space.

One frequently explored affective dimension is children's desires. Deleuze (1997) conceives the human body as one assemblage of machines (or heterogeneous elements) that produce desires. Based on this conception of the body as a desiring-machine, in children's play with objects (desiring with objects), the objects children interact with also offer desire; therefore, the body and the objects emerge something co-constructive in producing the affect of desiring. Inspired by this notion of desire, researchers such as Kuby and Rucker (2015) put forward the concept of literacy desiring, calling for studies of early literacy to focus on the present process of "the intra-actions of people-with-materials, -movements, and -surprises" when children engage in the process of making meaning and creating (p. 315). Therefore, literacy desiring encourages researchers to focus on affective dimensions and becoming embodied during literacy creations but not necessarily a future end product (Kuby \& Rucker, 2015; Leader \& Boldt, 2013).

In sum, scholars have drawn on different posthuman approaches to engage in early literacy research from a human-decentered standpoint. All these scholars embrace the vitality of materials and matters and zoom in on the intra-actions or in-the-moment transactions of both children and the materialistic world as they entangle and interact with each other.

\section{Research on Early Literacy from a Posthuman Perspective}

The literature search on major databases such as ERIC and Education Source using engines "early literacy", "post-humanism", "new materialism", "early education" generated a large number of results. After reviewing the major entires, a total of twenty journal articles and two books that closely examined early literacy education (2-10-year-old) from a posthumanism perspective were included in this review. Each selected article was further coded by topic/ontological foci and theoretical frames (which are shown in the tables listed below). After this round of coding, three overlapping strands of scholarship generated, namely, the reconceptualization of the child, the attention to the materials in childhood, and the reinterpretation of processes of early literacy development.

First, a group of studies (e.g., Jokinen \& Murris, 2020; MacRae, Hackett, Holmes, \& Jones, 2018; Murris, 2016;) focused on re-conceptualizing what accounts for the "child" within the changed adultchild/human-nonhuman boundaries from a posthuman viewpoint (see Table 1). New materialism disturbs boundaries not only between humans and nonhumans but also between adults and children. The changing boundaries evoke the scholars to reposition the child in relationships existing in the broader world, calling for a reconceptualization of the child as the embodiment of flexibility that transforms through its in-the- 
moment becomings with the nonhuman objects and the world and creating new possibilities for research and pedagogies of early literacy.

Table 1. Studies within the strands of reconceptualizing the child

\begin{tabular}{|c|c|c|c|c|}
\hline Study & Topics & $\begin{array}{l}\text { Age of the child } \\
\text { participant(s) }\end{array}$ & $\begin{array}{l}\text { Locale for collecting } \\
\text { the data }\end{array}$ & $\begin{array}{l}\text { The relevant } \\
\text { posthuman } \\
\text { approach }\end{array}$ \\
\hline Murris, 2016 & The posthuman child and picturebooks & $\begin{array}{l}6 \text { years old, } \\
8 \text { years old }\end{array}$ & $\begin{array}{l}\text { Home context, South } \\
\text { Africa }\end{array}$ & $\begin{array}{l}\text { agential realism, } \\
\text { rhizome, affect }\end{array}$ \\
\hline $\begin{array}{l}\text { Jokinen \& } \\
\text { Murris, } 2020\end{array}$ & $\begin{array}{l}\text { The posthuman child and vocabulary } \\
\text { learning }\end{array}$ & $7-8$ years old & $\begin{array}{l}\text { A literacy classroom, } \\
\text { Finnish }\end{array}$ & agential realism \\
\hline $\begin{array}{l}\text { MacRea et al., } \\
2018\end{array}$ & $\begin{array}{l}\text { The posthuman child and children's } \\
\text { becomings with materials in the } \\
\text { museum }\end{array}$ & 2 years old & $\begin{array}{l}\text { Manchester City Art } \\
\text { Gallery, England }\end{array}$ & $\begin{array}{l}\text { the child as "iii" } \\
\text { (Murris, 2016) }\end{array}$ \\
\hline Thiel, 2015 & $\begin{array}{l}\text { How the posthuman child and things } \\
\text { collaboratively co-constructed } \\
\text { meanings }\end{array}$ & $\begin{array}{l}5 \text { years old, } \\
6 \text { years old, and } 8 \\
\text { years old }\end{array}$ & $\begin{array}{l}\text { A community center, } \\
\text { the U.S. }\end{array}$ & $\begin{array}{l}\text { thing power, } \\
\text { assemblage, affect }\end{array}$ \\
\hline
\end{tabular}

The second strand of research (see Table 2) concentrates on the materials for young children's literacy development, or particularly the agential role of other-than-human entities in the embodiment of both representational literacies, such as discourses, texts, and artifacts, and non-representational practices, such as movements, sensations, and emotions (e.g., Lenz Taguchi, 2013; Thiel et al., 2019).

Table 2. Studies within the strands of the agency of materials

\begin{tabular}{|c|c|c|c|c|c|}
\hline & Study & Topics & $\begin{array}{l}\text { Age of the } \\
\text { child } \\
\text { participant(s) }\end{array}$ & $\begin{array}{l}\text { Locale for collecting } \\
\text { the data }\end{array}$ & $\begin{array}{c}\text { The relevant } \\
\text { posthuman } \\
\text { approach }\end{array}$ \\
\hline \multirow{7}{*}{$\begin{array}{l}\text { Represnetational } \\
\text { resources }\end{array}$} & $\begin{array}{l}\text { Lenz Taguchi, } \\
2010\end{array}$ & $\begin{array}{l}\text { Non-digital } \\
\text { resources }\end{array}$ & $2-3$ years old & A preschool, Sweden & $\begin{array}{l}\text { agential realism, } \\
\text { intra-action }\end{array}$ \\
\hline & Schulte, 2019a & $\begin{array}{l}\text { Non-digital } \\
\text { resources }\end{array}$ & preschoolers & $\begin{array}{l}\text { The playground of a } \\
\text { preschool, Sweden }\end{array}$ & agential realism \\
\hline & Schulte, 2019b & $\begin{array}{l}\text { Non-digital } \\
\text { resources }\end{array}$ & 4 years old & $\begin{array}{l}\text { A university-affiliated } \\
\text { preschool classroom, } \\
\text { the U.S. }\end{array}$ & agential realism \\
\hline & $\begin{array}{l}\text { Bendiksen, } \\
\text { Østern, \& } \\
\text { Belliveau, } 2019\end{array}$ & $\begin{array}{l}\text { Non-digital } \\
\text { resources }\end{array}$ & 3-5 years old & $\begin{array}{l}\text { A kindergarten setting, } \\
\text { Norway }\end{array}$ & agential realism \\
\hline & $\begin{array}{l}\text { Crescenzi, } \\
\text { Jewitt, \& Price, } \\
2014\end{array}$ & $\begin{array}{l}\text { Digital resources, } \\
\text { Touch (non- } \\
\text { representational } \\
\text { practices) }\end{array}$ & $1.5-3$ years old & $\begin{array}{l}\text { A nursery school, } \\
\text { London, England }\end{array}$ & intra-action \\
\hline & You, 2019 & Picture book & $\begin{array}{l}\text { Children at the } \\
\text { early age }\end{array}$ & N/A & agential realism \\
\hline & Murris, 2016 & Picture book & $\begin{array}{l}6 \text { years old, } \\
8 \text { years old }\end{array}$ & $\begin{array}{l}\text { Home context, South } \\
\text { Africa }\end{array}$ & $\begin{array}{c}\text { agential realism, } \\
\text { rhizome, affect }\end{array}$ \\
\hline \multirow{3}{*}{$\begin{array}{l}\text { Non- } \\
\text { representational } \\
\text { resources }\end{array}$} & $\begin{array}{l}\text { Hackett \& } \\
\text { Somerville, } \\
2017\end{array}$ & $\begin{array}{l}\text { Movement and } \\
\text { sound }\end{array}$ & $\begin{array}{l}2 \text { years old; } \\
6 \text { and } 7 \text { years } \\
\text { old }\end{array}$ & $\begin{array}{l}\text { A museum in England; } \\
\text { the backyard, the } \\
\text { nearby river, and places } \\
\text { in-between, Australia }\end{array}$ & $\begin{array}{l}\text { posthuman } \\
\text { theories of both } \\
\text { Barad and } \\
\text { Deleuze }\end{array}$ \\
\hline & $\begin{array}{l}\text { Harwood \& } \\
\text { Collier, } 2017\end{array}$ & Movement & Preschoolers & A forest school, Canada & $\begin{array}{l}\text { assemblage, } \\
\text { agency, intra- } \\
\text { activity }\end{array}$ \\
\hline & Wargo, 2017 & Sound and writing & First graders & $\begin{array}{l}\text { A primary school } \\
\text { classroom, the U.S. }\end{array}$ & intra-activity \\
\hline
\end{tabular}

In contrast to the attention to the materialistic entities, studies in the third strands pay attention to re-reading the nature of childhood and children's play through the posthuman lens (see Table 3). In particular, researchers in this vein look into literacies and practices generated from the human-nonhuman intra-actions and entanglements during children's play (e.g., Hackett \& Somerville, 2017; Leander \& Boldt, 2013; Procter \& Hackett, 2017; Wohlwend, Peppler, Keune, \& Thompson, 2017). 
A posthuman perspective on early literacy...

Table 3. Studies within the strands of reconfiguring childhood and children's play

\begin{tabular}{|c|c|c|c|c|}
\hline Study & Topics & $\begin{array}{l}\text { Age of the child } \\
\text { participant(s) }\end{array}$ & $\begin{array}{c}\text { Locale for collecting the } \\
\text { data }\end{array}$ & $\begin{array}{c}\text { The relevant } \\
\text { posthuman approach }\end{array}$ \\
\hline $\begin{array}{l}\text { Hackett \& } \\
\text { Rautio, } 2019\end{array}$ & $\begin{array}{l}\text { Children's play, } \\
\text { movements, multimodal } \\
\text { meaning-making }\end{array}$ & $\begin{array}{l}\text { Kindergarteners, } \\
\text { around } 2 \text { years old }\end{array}$ & $\begin{array}{l}\text { A kindergarten, Finland; } \\
\text { A daycare center, } \\
\text { England }\end{array}$ & $\begin{array}{c}\text { phenomenon, agency, } \\
\text { intra-action, } \\
\text { assemblage }\end{array}$ \\
\hline $\begin{array}{l}\text { Leander \& } \\
\text { Boldt, } 2013\end{array}$ & $\begin{array}{l}\text { Children's play, } \\
\text { movements, } \\
\text { Reading and writing }\end{array}$ & 10 years old & Home contexts, the U.S. & rhizome, assemblage \\
\hline $\begin{array}{l}\text { Wohlwend et } \\
\text { al., } 2017\end{array}$ & $\begin{array}{l}\text { Children's play, } \\
\text { makerspace, and } \\
\text { multimodal meaning- } \\
\text { making }\end{array}$ & 3-5 years old & $\begin{array}{l}\text { Three early childhood } \\
\text { classrooms, the U.S. }\end{array}$ & agential realism \\
\hline $\begin{array}{l}\text { Procter \& } \\
\text { Hackett, } 2017\end{array}$ & $\begin{array}{l}\text { Children's play, emotions, } \\
\text { fear }\end{array}$ & 2 years old & A museum, England & affect, agency \\
\hline $\begin{array}{l}\text { Kuby \& } \\
\text { Rucker, } 2015\end{array}$ & $\begin{array}{l}\text { Children's play, literacy } \\
\text { desiring, and writing }\end{array}$ & Second graders & $\begin{array}{l}\text { A writer's studio in a } \\
\text { second-grade classroom, } \\
\text { the U.S. }\end{array}$ & intra-activity \\
\hline Wargo, 2018 & $\begin{array}{l}\text { Children's play, digital } \\
\text { devices, sound, and writing }\end{array}$ & $\begin{array}{l}\text { Early elementary age } \\
\text { children }\end{array}$ & $\begin{array}{l}\text { A 6-week intensive } \\
\text { writing camp, the U.S. }\end{array}$ & $\begin{array}{l}\text { intra-action/intra- } \\
\text { activity }\end{array}$ \\
\hline
\end{tabular}

In the following sections, we detail the three strands of research followed by discussing the implications provided by these papers for future pedagogies and research.

\section{Rethinking the Child and In-the-moment Becoming}

Broadly speaking, studies on early literacy has experienced three main shifts in researching the child and childhood, namely, from the psychological territory to the sociological and then the philosophical domains, although the psychology of childhood continuously and paramountly impacts on policies, pedagogies, and practices of early childhood education (e.g., File, Basler Wisneski, \& Mueller, 2012; Murris, 2016). From the psychological perspective, scholars contributed to the early childhood education domain with numerous developmental-oriented theories, including paramount ones such as Piaget's theory of cognitive and Gesell's concept of maturation. Aligning with Piaget's learning theories and developmental trajectories, the child is seen as cognitive (or " $\mathrm{i}$ " [Murris, 2016]) and on a linear intellectual growth from an infantile, sensorimotor, and concrete stage towards an adult, operative, and natural-universal intelligence (e.g., Anderson \& Harrison, 2010; Burman, 2016; Jenks, 2005) where the world can be conceptually abstracted by and separate from children's mind. As a result, pedagogies and practices regarding early literacy keep pace with the children's developmental rule that they acquire literacy linearly "from the simple to the complex, from the particular to the general, from the concrete to the abstract, and from the empirical to the rational" (Egan \& Ling, 2002, p. 94).

Another perspective on researching the child and the childhood is socio-constructivist view that aims to understand how the child gains knowledge through and with the sociocultural milieu. The socioconstructivism into early childhood education questions the universal, ought-to-be, and linear stories described by using developmentalism, as well as the hegemonic position of developmental psychology in constructing policies and curriculum for the young. Socio-constructivist researchers employ alternative lens such as feminist, poststructuralist, postcolonial, and postmodernist theories to explore the roles of political, social, and cultural powers playing in children's learning and life. Several seminal works in the socio-constructivist vein regards childhood as an invention of culture and society (Aries, 1962), or as a social construction (Alanen, 1988), as well as seeing the child as "social agent" (Cregan \& Cuthbert, 2014, p. 12), or "ii" (Murris, 2016), which is "discursively produced through a process of social and cultural signification" (MacRae et al., 2018, p. 506), thereby disturbing the cognitive position of the child as an "object of cognitive science" (Murris, 2016, p. 84).

While the socio-constructivism expands the concept of the child, it does not address the shifting boundaries between humans and nonhumans and between adults and children. These gaps in our understandings invoke more philosophical discussions of what counts as literacy, the child, and childhood, 
mostly from the posthuman lens. Researchers in the posthuman view question the aforementioned two constructions of the child as "a pre-determined map" (Olsson, 2009, p. 13) and childhood as an absence of adulthood, indicating that the child "perpetually becoming and not being defined once and for all" (p. 14). By reconfiguring the nature of the child with posthuman theories, researchers articulate the child's body as an unbounded organism that exists in a human-nonhuman entangled network of the world rather than representations contained in the linguistic- and humanist-oriented discourse nor production from a prescriptive, normative developmental process. So, for example, Murris's (2016) groundbreaking work detailed the posthuman construction of the child-the child as "iii", or the posthuman child. The posthuman child, as Murris elucidated, pays more attention to the not-yet-known beginnings that are "taken up and materialized in intra-action with other human animals and nonhuman others" (Murris, 2016, p. 102). A new materialist lens foregrounds the materiality of children's bodies in their entanglements with objects and the more-than-human world. It shifts the focuses from "what the child is" to "who, when, and where the child is with". In this vein, the child is seen as a "unique and singular being with fluid boundaries comes into the world" (p. 102). Thus, this notion of the posthuman child invites researchers and educators to take up their investigations and interpretations about children's learning and development from a new lens.

MacRae and her colleagues (2018) detailed how these different conceptions of the child can lead to a different understanding of the child by reinterpreting data with the "iii" perspective on a two-year-old girl's encounters with space and objects (e.g., sponge) in a museum gallery. From a cognitive viewpoint, the girl's mental concepts were developing, and her learning moved from concrete to abstract as she manipulated the objects as instruments to develop her conceptual and logical knowledge. Secondly, the socio-constructivist lens led researchers to interpret the sponge that Matilda's play with as a cultural signifier, which afforded potentials for the planned learning (i.e., naming the sponge by using language) conducted between Matilda and the accompanying adults. Through the posthuman lens, the authors shifted their attention to the agentic role of the "still" sponge and other objects in the museum in interactions and entanglements with Matilda and space, noting that the sponges "emanated desire, driving Matilda to reach for them, and stoke them across her cheek" (p. 508). Matilda's seemingly repetitive movements were viewed as qualitatively-different thinking and becomings that occur in the dynamic flow of movements, or simply, "improvisational threads of variability" (Manning, 2016, p. 2).

Thus, the materialist approach altered the researcher's understanding of the child to reconsider children's being/knowing/doing literacies by highlighting the dynamic and ongoing becoming of humans, nonhumans, and the more-than-human world. For instance, Thiel's (2015) explored how the posthuman child and things collaboratively co-constructed meanings by examining three children $(5,6$, and 8 years old) from low socioeconomic families of the southeastern US and their encounter with a box of fabric remnants in their playroom. From a new materialist lens, the fabrics served as actants that propelled children's work, including designing/imagining, manipulating tools, and crafting pieces for fantasy characters (e.g., warriors) in their superhero stories. Thus, both children and the things were transformed in the intra-actions among them.

From a posthuman lens, the child's body is part of the materiality. Jokinen and Murris (2020) illustrated this point in their posthuman interpretation of 7-8-year-old immigrant children's hands with/in visual images of body-part vocabulary in a second language lesson in a Finnish elementary classroom. With the posthuman lens, the hands, along with the movements and actions of children's hands such as lifting, stretching, holding smartphones, and touching the game board, were seen as engaging in embodied entanglements with each other. Building on Haraway (2016)'s term, sympoietic, which means "makingwith" or "thinking-with" (p. 58) and implies the ongoing becomings of both human and nonhuman bodies, the two authors further reconfigured the child in literacy practices as a sympoietic phenomenon that is "always already assembled in human and more-than-human company" (p. 46). 
A posthuman perspective on early literacy...

\section{The Agency of the Materials and Contexts: Representational and Non-representational Resources}

Studies draw on the posthuman approaches acknowledge the mutually-constitutive relationship of children, materials, and contexts. With the posthuman lens, the scope of materials for children's literacy construction has been expanded by including all matters, both tangible (such as semiotic and digital) and non-tangible (such as actional, sonic, and emotional) resources. Most of the research in the stream moves beyond the conventional, prevalent representational materials for children's literacy learning such as pens and books to include a wide range of semiotic objects such as sticks, ribbons, and the untimely dead bird, digital technologies embedded in children's daily practices for current times (e.g., Crescenzi, Jewitt, \& Price, 2014; Lemieux \& Rowsell, 2020; Lenz Taguchi, 2010). As well, the posthuman reading of early literacy recognizes literacy practices as ongoing, unstructured, and fluid, moving the understanding of children's literacies from children wielding materials to meanings generating through entanglement between children and the more-than-human materialistic world, including actions, movements, sounds, and words.

Picture books. In early literacy, teachers often use texts such as picture books to support children's reading. A small number of researchers have re-examined the traits of children's picture books with the new materialist lens and discussed how to include picture books to generate intra-actions of children, space, text, and other objects emerging more children's experiences and literacies practices through these engagements.

From the human-decentered perspectives, You (2019) examined the significance of diverse forms of depicting the animal gorilla in children's picture books Gorilla and Zoo composed by Anthony Browne. In Browne's picture books, the gorilla and other zoo animals were endowed with diverse anthropomorphic emotions and behaviours, representing the author's ethical position against the dominant human gaze to the nonhumans. The anthropomorphic gorilla described in the books entangled with and contrasted to children's previous experience of animals imprisoned in the zoo cages, further inviting them to ponder the animal issues with "an emergent sense of ethical responsibility" (You, 2019, p. 34). When children encounter the human-animal contact intertangled at the realistic and allegorical levels in the books, they can gain "a renewed intellectual and affective sense of environmental care", rather than just symbolically read the book.

Focusing on Browne's another book Little Beauty, Murris's (2016) study demonstrates how the "silent" materiality (e.g., colours, lines, and drawing styles) of picture books saliently affects the ways of constructing meaning through unpredictable, dynamic, and material-discursive entanglements between children and the picture book. By reinterpreting the data of a home-reading activity between two girls (6-year-old and 8-year-old) and their mother on Little Beauty, Murris noted that the realist imaginary drawings in the book, the colour selected in one specific drawing, and the storyline prompted children to ponder and question human-animal, real-life-made-up, and truth-telling-lying distinctions, to connect with their prior experience and knowledge, and to create an empathetic relationship with the gorilla. The posthuman reading of the reading activity also indicated that the picture book provides both the adult (the mother) and children (two girls) with creative opportunities to destabilize discriminatory binaries as provocations for communities of enquiry, and thereby disrupts the adult/child dichotomy by valuing children's capacities of knowledge construction. As a result, children's processes of knowing/becoming/doing literacies are facilitated by the probing, open-ended questions emerging in equal adult-child interactions built on the book.

Representational and semiotic resources. To date, several studies have focused on non-digital materials, including traditional pens and papers and other semiotic resources, surrounding and entangling with children in producing knowledge and practices in specific time and space. The resources encompass a wide range of human-nonhuman entities ranging from a small one (e.g., a yellow lemon) to a large item such as a dump truck with big tires.

Lenz Taguchi's (2010) study focused on the agentic role of children's play sticks in contributing to 2-3-year-old preschoolers' literacy development. The study documented the agentic forces of various material realities such as wooden sticks, shiny papers, and coloured ribbons that propelled children to 
discursively think about and creatively transform the stick as guns, swords, and stick-dolls in intra-active processes between children, the teacher, and materials. Simultaneously, the discursive transformations of the sticks played an active role in shifting patterns of children's play. When children, especially boys, entangled with wooden sticks as guns and swords, children's play became war games; while children encountered with the stick, the thoughts of naming the stick, and coloured ribbons/papers, the play was transformed from aggressive to warm and inclusive, further attracting girls to take part in the stick-dollmaking process. Subsequently, along with the doll-making play, children began to wonder about how the stick had been one part of a tree and how the tree as a part of nature depended on natural elements such as sunshine and soil. Lenz Taguchi thus stressed that "it is the material-discursive forces and intensities that emerge in the intra-actions in-between the child and the materials in the room that together constitute the learning that can take place" (p. 36).

In Schulte's (2019a) study, the material that served as an active actant in producing literacies was an untimely-dead bird that suddenly emerged near a playhouse at the far end of a playground. The study vividly depicted how children's bodies detached from their previous contexts scattering in the expansive playground to the magnetic space where the bird fell. Schulte noted that the sudden death of the bird "effectively transformed the children's interests" and entirely "redirected the focus of their endeavouring" (p. 73). The complicated encounter of the bird, children, space, and time generated newness and differences of children's thoughts, emotions, movements, and actions, further transforming the patterns of children's becomings and knowing individually and collectively. For the individual shifts, a boy became a little scared with a tense body and partially hid his body behind one girl, while a girl showed her sorrow and readied a dandelion to place on the bird's head. For the collective shift, a discussion of the reasons why the bird died emerged among children, further evolving as a mining of children's prior memories and experiences with similar occurrences and an exploration of life and death. Meanwhile, a collaborative work of digging the bird's grave was done by the children. With the posthuman interpretation of the encounter between children and the bird, Schulte affirmed the vibrant agential role the death of the bird played in generating a material occasion and potential literacies for young children.

Another research of Schulte (2019b) documented how humans and nonhumans intra-acted with each other to produce "undeniable signifying forces" (Iovino \& Oppermann, 2012, p. 2) in the drawing practices of a four-year-old boy, Andrew, in a childcare center. In the study, a dump truck occasionally idling outside of the classroom window served as a key operator and a decisive agency that catalyzed the interlocked transformations of Andrew's body, mind, and his drawing, for instance, the emergent dilemma of whether to draw a truck as the truck appearing, the eyes fixed on the intersection to check if the truck would reappeared, the exciting shout bursting when the truck showed up, and the newly-added lines, circles, and dots in the drawing which represented the truck, the road, and the rock carried by truck. Similarly, Bendiksen, Østern, and Belliveau (2019) re-read three literacy events that occurred from writing play activities for children between three and five years old. Barad's agential realism scaffolded the researchers to recognize the performative nonhuman agents such as the treasure chests, the yellow lemon smell and taste, the flat iron, the mood of expectancy, the blackboard that intra-acted with human agents such as teachers, children, and the researchers in producing practices, knowledge, and experiences concerning linguistic awareness, handwriting, and meaning-making. Both of the two studies added evidence to the vital agential force of materials in producing literacies for the child.

In addition to various non-digital resources for early literacy, a growing number of early childhood education research also seeks to develop a better understanding of how the differences between the conventional paper-based resources and digital tools lead to different ways of child-material entanglements and therefore different ways of children's being/knowing/doing with literacies. For instance, Baroutsis and Woods (2019) considered both print and digital materials (such as papers and digital devices) and proposed makerspace (usually a collaborative workspace in the schooling contexts) as a pedagogical approach. They designed three problem-solving activities to discover how the materials of a makerspace altered the composition of first graders growing-up in a high-poverty community. Specifically, the three play-based makerspace activities are respectively themed by the Hansel and Gretel 
A posthuman perspective on early literacy...

fairy tale, children's prior experiences about something interesting happened last week, and the life in a fish tank. In Baroutsis and Woods's posthuman observation, different materials acted as active agents and took part in the construction of multiple realities (including children's written stories), producing ample practices and encouraging children to highly engage in writing and become more efficient and effective thinkers. For instance, during the second activity, the interesting things occurring in the previous week, the children, the papers, ribbons, glues, etc. intertwined with each other and generated new forms of practices (e.g., making a spaceship, moving around the room to check other peers' work, and writing sentences to describe the artifacts created), emotions (e.g., children's enjoyment in the play-based activities; the pride that children demonstrated in their writing), and material realities (e.g., a spaceship, an alien, and a written text about the alien sighted last week).

Besides, Crescenzi et al. (2014) explored the role of screen touch in preschool children's learning to use an iPad versus paper interaction. To compare how touch features in painting with a tablet versus painting with paper, the researchers found that while digital mobile devices afforded children a wider variety of touch-based interactions, they also cause some "losses" that need further considerations in education for young children.

Children's non-representational practices: Movement and sound. Existing literature also explored how movements scaffold children's literacy learning by reconsidering the active moving-space-material actants in human-nonhuman interactions, which produce new patterns of literacy practices and learning for young children. The posthumanist perspective re-reads children's movements as unfolding relations in which space, time, and matter are always entangled (Barad, 2013). In other words, movements are rhizomatic, unprepared, and improvisational child-material interactions existing in the past, present, and future. Particularly, sound is defined as a vibrational movement at a molecular level (Gershon, 2013). Therefore, a growing number of existing literature in this vein turn to explore the dynamic and contingent child-object-matter-space encounters such as movements and sounds that generate discursive practices and literacies for children in specific spaces such as museums, galleries, and forests (e.g., Hackett \& Somerville, 2017; Harwood \& Collier, 2017; MacRae et al., 2018; Procter \& Hackett, 2017).

Hackett and Somerville (2017) reported two studies of emergent literacies conducted in the UK and Australia. For the year-long UK study, they drew data from monthly visits of a group of two-year-old children in a local museum and captured some "child-led traditions" such as marching while banging the drum that repeatedly emerged during the children's visits. The posthumanist analysis showed that different locations in the museum (e.g., a small gallery and corridors) and the drumstick played a crucial role in the production of movements (e.g., drumming, marching) and sounds (e.g., banging, shoe scuffing). The movements and sounds further synergically created diverse and influential affective responses between children, materials, and the museum. The affective properties of movements and sounds consisted of children's non-linguistic utterances, which collaboratively produced representative and communicative practices and participated in the world-forming moment by moment. For the Australian study, two six and seven-year-old girls' stories, sentences, and commentaries emerging during play with mud nearby a river were incorporated. Drawing on Barad's (2007) concept of agential realism, Hackett and Somerville regarded the sounds and words as vibrations driven by the mud and the water. Both the two studies revealed that different repertoires of literacy practices emerged spontaneously through the shared becomings of children (humans), materials such as the drum, the water, the mud (nonhumans), and the more-than-human world that sounds and movements partially constituted. As the researchers noted, "posthuman readings of early childhood literacy offer the possibility to shift the narrative and to reconceptualize emergent literacy in ways that reconcile with young children's being in the world" (p. 389).

Another example of children's movements is Harwood and Collier's (2017) research that aimed to illustrate interactions among children and nonhuman others in a forest setting by detailing the ways of how sticks coexisted with children's bodies, elicited actions, sounds, movements, and relations, and produced new possibilities for children to learn literacies and develop identities. The authors argued that matters such as sticks and movements with sticks in the forest played as powerful agents to children's playful literacy practices that were "constantly in flux" (p. 350), thus inviting infinite possibilities for 
literacy teaching and learning. They concluded that the world of a forest which was awash with human and nonhuman forces had enriched resources and capacities of early literacy education.

A small amount of the posthuman research focuses on the lesser-known modal resource such as sound in early writing (e.g., Wargo, 2017, 2018). Thinking with conceptual approaches of sound studies and the posthuman ways of being/knowing/doing/becoming, Wargo (2017) analyzed a digital audio clip and a tableau that documented first graders' writing with sound in the classroom and the sensations and thoughts emerging alongside children's composition. Through investigating the rhythmic rituals of "emergent listening", Wargo emphasized that the sound and the sonic (e.g., a chorus of classroom claps and tapping the canvas with fingers) as the explicit material referent actively effected on generating different forms of embodied encounters (e.g., inviting children to collaboratively come together, creating boundaries of place and community for children as readers or writers, or shifting acoustic ambience of the classroom) when children and other nonhuman entities such as the mass-produced microphone Yeti, hands, shoes, and the laughter entangled with each other in the classroom. Wargo further encouraged researchers and educators of early literacy to ponder the modal affordances of sounds to pedagogical shifts to generate new creative energies of knowing and doing literacies in the classroom.

\section{Rethinking Children's Play: Literacies, Emotions, and Literacy Desirings}

Building on inquiries about the relationality between bodies and the otherness or the materials, a group of scholars sought to use the posthuman lens to understand the process of "bringing-into-relation" (Weheliye, 2014, p. 13) emerging between these entities, particularly the impromptu, entangled, and fluid encounters during children's play (e.g., Hackett \& Rautio, 2019; Lenz Taugchi, 2013; Sintonen, 2020). In this context, children's play is seen as a space where children, objects, and places play with and are played back by each other in and with material-discursive contexts (e.g., Jones \& Holmes, 2014; Lenz Taguchi, 2014).

Literacies emergent in and through play. Hackett and Rautio (2019) analyzed children's grass-hill rolling in the UK and running in a pine tree forest in Finland to understand what multimodal meaningmaking might emerge. Approaching children's running or rolling as forms of correspondence or relationship with the tree, the steep grassy hill, and the other things existing in children's surroundings, the researchers discovered the children produced particular kinds of embodied multimodal meaningmaking, in response to the pine tree, bugs, the wind and the sand while running or rolling, a process that was collaboratively "brought into being" between the human (children) and more-than-human participants (tree, bugs, sand, hill etc.) involved in the relationships. In this "process of growth and ongoingness" (p. 1026), a shared meaning emerged over time without pre-intended goals. Hence, Hackett and Rautio emphasized the non-predetermined and emergent nature of involvement of the more-thanhuman multimodal meaning-making, which was not productions or skills that children possessed or intended to possess. Instead, it should be understood as "pathways and channels... for the voices and stories of the world" (p. 1025).

Drawing on the same framework, Leander and Boldt (2013) studied a ten-year-old Japanese boy's one-day out-of-school practices - reading and playing with texts from the Japanese manga series InuYasha and Naruto. While the boy was reading, the researchers observed constant and unpredictable nonrepresentational and unconscious actions (e.g., the boy retrieved one headband from his bedroom, frequently touched or adjusted the headband, practiced hand gestures, and rearranged knives while reading the manga), feelings (e.g., the boy articulated, "I love this so much" at times), and movements (e.g., the boy and his friend moved freely from the living room to the front yard, swung the sword at each other, and played the scenes from the manga book). These assemblages of discursive things presenting in the reading and play (such as the performing scene) transformed the boy from being identified as a struggling reader and writer to a book fan who sank into the chair and read and thought for a couple of hours. Therefore, as the authors noted, to the boy, literacy activities were not "projected toward some textual endpoint" but "living in its life in the ongoing present" (p. 27). In short, literacy practices for children can be produced "through an emergent moment-by-moment unfolding" (p. 29). 
A posthuman perspective on early literacy...

Wohlwend et al. (2017) added further argument for the strength of the posthuman notions in interpreting children's play as emergent early literacy learning processes by re-examining the previously overlooked moments filtered out as meaningless and mess during children's play in a preschool makerspace. They recognized the fluid meaning production during the nonsensical play by tracking the emergent and transient flows of interactions between children, materials, and the preschool makerspace. Through a new materialist lens, Wohlwend and her colleague granted these overlooked moments such as non-representational experiences and the free-wheeling nonsense existing in children's play as literacies that are "both sense-making and sensory" (p. 445). Thus, instead of the conventional and extended interpretations of children's play, they brought newness to the notion of early literacies during play.

Emotions in the playful childhood. Affect and emotions, particularly for young children, have close interconnections (Shouse, 2005) as emotion is "the capacity to affect and be affected" (Massumi, 2002, p. 15). Much research in early educational studies have been directed towards shaping children's emotional worlds through play-based approaches, seeing children's play as a therapeutic mean of helping children to regulate their emotions (e.g., Savina, 2014; Zachariou \& Whitebread, 2015). Different from these approaches, the new materialist research turns to emotions and bodily sensations as offering agencies in understanding the significance of children intra-acting with place and materials with play encounters (e.g., Pahl, 2014; Procter, 2013; Rowsell, as cited in Leander et al., 2017), seeking to develop the attributes associated with emotional wellbeing such as emotional literacy.

A notable example of work in this area is Procter and Hackett's (2017) study on the "dark emotions", such as fear, showing that how emotionally-textured play of children, materials, and spaces is mediated within material-discursive contexts. Procter and Hackett brought together two case studies to understand the emotion of fear in children's play encounters. One example regarding young children recorded a twoyear-old boy's movement and emotion trajectories during one museum visiting: He repeated to express his fear while keeping moving in and out of place to explore a natural history exhibition. The exhibition's materiality, including light and exhibits, induced the boy's intensities and propelled his bodily movements to enter and leave the space. In the two play episodes, Procter and Hackett found that the emotion of fear was "bounded in place" (p. 220). The bodily experience of the place and materials worked on children, evoking certain emotions that, in turn, acted on characterizing and categorizing human and nonhuman bodies. In this case, Procter and Hackett foregrounded the agential role of the complicated materialdiscursive forces in the more-than-human world, calling for extensive attention to the possibilities and conditions produced by the place and materials for establishing children's experiences. The study implies that educators need to take seriously children's emotional experiences in place and how the emotional experiences connect with children's body, objects, the play, and the space in order to offer opportunities for children's practices including both metanarratives and representations "of self and other, of what counts as human and less-than-human" (p. 223).

Literacy desirings. Seeing play as the process of children becoming literacies opens spaces for children to live out their literacy desirings or "the present processes of producing - a force, a becoming, a coming together of flows and intensities" (Kuby \& Rucker, 2015, p. 315) through entanglement with intangible and tangible others in their realities. For instance, in their 2015 study, Kuby and Rucker tracked the process of production and becoming a writer of a boy, Neil, who showed no passion for writing before. Through a human-decentered lens, researchers witnessed the boy's intra-acting with papers, scissors, pencils, and tape that generated peers' interests in Neil's 3D artifacts - a station and a train, and the emergent Neil-peer-teacher questions and conversations about how the artifact worked and how Neil's story of the train would be composed). Significantly, the process brought shared becomings of the materials (papers transforming and being transformed into the 3D artifacts) and Neil himself shifting from a student who did not like writing to both a confident expositor and a writer who desired to share the information of his creation. These unexpected and off-task moments emerging from the intra-actions between children, materials, and others in the writers' studio served as spaces where the ongoing process of production was realized and simultaneously opened up new possibilities of producing literacy desirings.

Also focusing on children's composition process, Wargo (2018) studied 12 early elementary-aged 
children reauthoring Showers's picture book The Listening Walk in a 6-week creative writing camp in the US. The author was particularly interested in how children wrote creatively with the wearables-digital technologies such as iPads and GoPro with fundamental functions requiring connections with bodies. Through the more-than-human apparatus, including strategic sketches (Leander \& Boldt, 2013) and emergent listening (Davies, 2014), the study looked into the relational assemblages of children, head harness, boom mic, and the sonic affordances of the GoPro wearable that worked to amplify the ambient acoustics of the father-child walk described in The Listening Walk. Wargo envisioned writing as a process of literacy desiring or an "ongoing series of relational encounters" (p. 504), rather than a practiced skill. The study's findings demonstrated that the intra-actions, or the withness between children, composition, and materials expanded children's literacy desirings and practices that effected their potentials of being and becoming a writer.

\section{A Posthuman Approach to Early Literacy Instruction: Toward Material-oriented, Intra-active, and Flexible}

The three strands of scholarship reviewed in the current paper provide important implications for early literacy instruction. Collectively, the studies move the field towards a material-oriented, intra-active, and flexible pedagogy that is open to possibilities and unexpectedness emerging in literacy teaching and learning for young children. Instead of the conventional anthropocentric (human-centered) and logocentric (language-focused) approach to early literacy (e.g., Akhter, 2016; Heider \& Renck-Jalongo, 2014; Jesson, McNaughton, \& Wilson, 2015), the posthuman stance beckons scholars to question the taken-for-granted conceptions about what counts as literacy for young children, to focus on the processes of becoming instead of the end products of meaning, and to move beyond 'justice-to-come" (Barad, 2009, n. p.) but the present, "a better, more just right now" (Kuby et al., 2019, p. 13).

From a posthuman perspective, children are regarded as parts of "an entangled web or network of relationships" (Lenz Taguchi, 2010, p. 152), who continuously intra-act with their peers, teachers, materials, and the other more-than-humans (e.g., practices and activities produced continuously by the child-material entanglements). For instance, as Murris's 2016 study noted, except for the content of pictures in the book, the colors, the painting styles and even patterns of lines used to sketch the contours of figures collaboratively contribute to children's empathic emotions to the gorilla and the communications about equity generated between the two girls and their mother. Also, Bendiksen et al. (2019) described how the strong smell and taste of a yellow lemon brought various sensuous experiences to children, then provoking children's impromptu writing practices with their fingers, the lemon juice "ink", and papers. In the two cases, the notion of the picturebook or the lemon moves beyond our conventional understandings of them as reading materials that are set out for children to read and comprehend or fruits that are wait to be described through children's textual outcomes. Instead, the material traits make them become "performative agents" (p. 15) that scaffold unpredictable practices when they are encountering with children, time, and contexts, opening up children's opportunities of accessing and producing literacies and therefore, increasing children's engagements in literacy events. These examples may guide early educators to rethink what counts as materials in early literacy education as flexible other than the conventional ones which are "closely connected to making" and "are often set out for children to make or create something with" (Pacini-Ketchabaw, Kind, \& Kocher, 2017, p. 26). Hence, teachers need to be aware of how the context, time, and materials are organized and allocated and what kinds of knowledge, experience, learning, and practices might be produced within the intra-activities between children, materials, and the places where children and materials are engaging with each other and with the contexts (Leander \& Boldt, 2013; Lenz Taguchi, 2010). That is, teachers need to "think with" materials (Pacini-Ketchabaw et al., 2017), being sensitive about the inclinations and potentials of different materials in producing in-the-moment practices such as bodily emotions and movements generating from child-material entanglements in certain contexts.

As well, teachers need to move beyond pursuing children's textual products as the endpoint of literacy practices and become attentive to the production process of children's in-the-moment practices. 
A posthuman perspective on early literacy...

Sintonen (2020) showcased how teachers can pay attention to intra-activity in early literacy instruction through her reflective autoethnographic consideration of two distinct learning processes of creating artifacts, conventional acrylic painting and digital painting. Sintonen observed that compared with the conventional acrylic painting with papers, painting with digital tools involved more modes, affects, and affordances, therefore different intra-actions and meanings. Therefore, for young children, educators need to make a thorough consideration of how different materials are manifesting and modulating ways of meaning-making. In particular, Sintonen stressed the critical focus on the "sensory, embodied, experimental, and playful intra-actions" among "unforeseen smooth spaces and material invitations" (p. 1330). Furthering Sintonen's argument, Baroutsis and Woods (2019) proposed the concept of "literacy as material practices" (p. 250), which highlights the agentic role of the material (including the discursive and the virtual as well) working with the child and the more-than-human world in producing literacies. In their study, they closely observed how changing materials from non-digital such as ribbons to digital such as iPads changed and afforded the text production of children in a makerspace, suggesting "makerspace as a pedagogical approach" (p. 251) where teachers can shift the focus from materials to the dynamic and the discursive when children playing with various human and nonhuman bodies. Teachers, as the study suggested, may also abandon conventional desk-chair classroom-arrangement and hide themselves in "a mess bodies scattered across the room" (p. 263) to offer children's freedom to access other bodies and further make full use of the classroom space. By creating inclusive spaces and decentering teachers' roles in the play-based makerspace, children, especially the ones who are reluctant to write and disengaged with literacy learning, can gain increasing opportunities for literacy learning in the classroom.

Moreover, with a posthuman lens, early literacy instruction can become more inclusive by embracing the out-of-classroom world for children's literacy acquisition. The opportunities of children's becoming and knowing literacies can be generated as young learners encounter a bird falling down onto the playground, a wooden stick found in a forest, a truck occasionally passing outside of the classroom, a spatial museum gallery, or a grassy hillside. In a sense, the children's educational settings are "[fields] of possibility" (Koepke, 2015, n. p), presenting infinite possibilities of supporting children's literacy learning with the objects, the context, and experiences "that are at hand" (n. p.). In these contexts, the materials, the materiality of human bodies, and the more-than-human world can collaboratively serve as tools for the enacting of literacy education for children. In this sense, early literacy educators need to become cognizant of the human-nonhuman relationality and rearticulate their understanding of early childhood education as an assemblage of the child, materials, and the space, and knowledge as "a product of relation" (Hargraves, 2019, p. 192).

In addition to celebrating child-material entanglements and de-territorializing spaces, teachers also need to remain flexible and open to hear children's desirings, as well as allow children's literacy desirings to live out (Kuby \& Rucker, 2015). Studies (Kuby \& Rucker, 2015; 2020; Kuby, Rucker, \& Darolia, 2017) advocated that teachers need to break the rigid structures of literacy instructions, embracing fissures occurring in the curriculum agenda. Teachers should not only value children's creations that were purposefully made for communications but also their "sometimes unpredictable...collaborative processes of creating and the assortment of artifacts they (might) produce" $(2015$, p. 326). Permitting children to use open-ended materials in ways that make sense to them would also generate more children-material interactions and subsequently produce expansive practices and activities concerning literacy in the classroom. That is, when given the material-time-space opportunities to pursue their desirings of literacy, students may then be/know/become literacies in the ways beyond our imagination.

Finally, several studies (e.g., Kuby \& Crawford, 2018; Lenz Taguchi, 2010; Wargo, 2018) suggested several tangible practices for early childhood educators to study their own practices in creating in-themoment improvisational unfolding of early literacy. For example, educators can work as educational researchers, watching, teaching, and learning with children, such as inviting children to participate in the design of the curriculum to listen to children's literacy desirings. Simultaneously, teachers can document their pedagogical and teaching experiences by using a mosaic approach (Clark \& Moss, 2001), including educator journals, photos, and videos and flexibly letting children chronicle their own learning experiences 
into the document. The pedagogical documentation is not about a recording of "knowledge or the progress of learning goals" but rather "...what questions have been produced... what kinds of materials and tools have been tried, and what are the potentials for continuing" (Kuby \& Crawford, 2018, p. 22). Also, teachers can reimage the use of instructional tools and materials commonly used in daily literacy classroom, for instance, linking the picturebooks with the natural-cultural world by adding aural and actional dimensions to the figurative but static texts to open up children's subsequent practices such as discussions and play. Teachers can also include the out-of-classroom settings such as playground, museum, and forests as the place of instruction, inclusively viewing materials and the space as performative agents in leading pedagogies and embracing any potentials of materials and the place that learning may take place.

In sum, the posthuman lens encourages early childhood educators to combat the "institutionalized ageist practices" in early instruction (Murris, 2016, p. 1) and offer alternative pedagogical possibilities. Teachers of young children (as well as parents) need to become attentive to a broader range of materials, time, and spaces for literacy teaching and learning.

\section{Conclusions and Future Research Directions}

The review of research on early literacy revealed that the posthumanism perspective offers expansive possibilities for reconceptualizing the child, the materials or resources for early literacy, and the meaning of childhood and children's play. Researchers with a posthuman lens move beyond a humanist worldview that locates learning in individuals to see children's learning as "a cooperative and communicative activity" (Murris, 2016) in which children actively co-construct knowledge with the other human-nonhuman bodies and entities. This reconfiguration of the child shifts from viewing children as passively receiving knowledge, language, and concepts to valuing children's active role in being/knowing/doing knowledge moment-by-moment.

Posthuman researchers also expand the view of materials for children's literacy learning from predesigned and intentional resources for literacy (e.g., textbooks and teaching materials) to all tangible and intangible matters entangled within the process of producing literacies. These tangible and intangible matters can be sticks in the forest, emotions emerging in the museum, and sounds during the march with the drum. All these matters, intertwining with the specific places at the specific time, serve as agencies in the interactions between the matters and the children to produce moment-by-moment practices and literacies. The recognition of the agential power of matters and materials in producing literacies helps educators to reconsider what resources can be used to support children's literacy development and how the resources serve as part of the children's meaning-making.

This review revealed several gaps in the contemporary research and education of early literacy. First, with a few exceptions, most of the existing studies focused on toddlers and preschoolers. More studies on young children at the primary school age do literacies in both in- and out-of-school contexts, and how they reconcile with formal assessments are still required. Furthermore, whereas the researchers are productive in using the posthumanist lens to explore materials in contexts focusing on children's moment to moment becomings, few studies have taken up a critical view of the posthuman child and early literacy by examining the inequalities that may embody in the children's intra-active experiences. Thirdly, although emerging studies has demonstrated possibilities in grounding posthuman theories in early literacy pedagogy, future research still needs to explore how posthuman theories can transform educators' theoretical beliefs and practices in educational settings for young children.

Finally, it must be noted that one limitation of this review is that it did not touch upon research methodologies from a posthuman perspective. Future research must focus on methodological questions for conducting studies from a posthuman lens (e.g., Toohey et al., 2015). Major methodological questions may include, for example, 1) what are possible ethical issues when applying posthuman theories to research literacy education that is conventionally a human-oriented domain; 2) what interpretative dilemma we may have when moving from a traditional anthropocentric (human-centered), logocentric (language-centered) stance toward the ontological tenets of posthumanism, especially in thinking about 
A posthuman perspective on early literacy...

and researching children's literacy teaching and learning; 3) what alternative orientations and methods for data analyses are needed to address the ethico-onto-epistemological paradigmatic shift to open up newness about researching early literacy; and 4) what problems regarding reliability and accuracy may arise, for instance, how to document children's discursive, emergent, and complex non-representational communicative practices (e.g., emotions and movements) comprehensively and how to interpret the ongoing mutual becomings between the child and the outside world. More methodological discussions are needed to wrestle with these critical questions in the future.

\section{Declarations}

Acknowledgements: Not applicable.

Competing interests: The authors declare that they have no competing interests.

Funding: This manuscript and work was not funded by any funding agency or grant.

\section{References}

Akhter, P. (2016). A young child's intergenerational practices through the use of visual screen-based multimodal communication to acquire Qur'anic literacy. Language and Education, 30(6), 500-518. https://doi.org/10.1080/09500782.2016.1141935

Alanen, L. (1988). Rethinking childhood. Acta Sociologica, 31(1), 53-67. https://doi.org/10.1177/000169938803100105

Anderson, B., \& Harrison, P. (2010). The promise of non-representational theories. In B. Anderson \& P. Harrison, Taking-Place: Nonrepresentational theories and geography (pp. 1-36). Farnham: Ashgate.

Aries, P. (1962). Centuries of childhood: A social history of family life (R. Baldick, Trans.). New York, NY: Alfred A. Knopf.

Barad, K. (2007). Meeting the universe halfway: Quantum physics and the entanglement of matter and meaning. London: Duke University Press. https://doi.org/10.1215/9780822388128

Barad, K. (2009, June 6). "Matter feels, converses, suffers, desires, yearns and remembers": An interview with Karen Barad. New materialism: Interviews \& cartographies. Retrieved from https:/quod.lib.umich.edu/o/ohp/11515701.0001.001/1:4.3/--new-materialisminterviews-cartographies?rgn=div2; view=fulltext

Barad, K. (2013). Ma(r)king time: Material entanglements and rememberings: Cutting together-apart. In P. R. Carlile, D. Nicolini, A. Langley, \& H. Tsoukas (Eds.), How matter matters: Objects, artifacts, and materiality in organization studies (pp. 16-31). Oxford: Oxford University Press. https://doi.org/10.1093/acprof:oso/9780199671533.003.0002

Baroutsis, A., \& Woods, A. (2019). Materialities, multiliteracies and makerspaces: Design-based experiments in teacher/researcher collaborations. In N. Kucirkova, J. Rowsell, \& G. Falloon (Eds.), The Routledge international handbook of learning with technology in early childhood (1st ed., pp. 248-264). London: Routledge. https://doi.org/10.4324/9781315143040-18

Bendiksen, S. Å., Østern, A., \& Belliveau, G. (2019). Literacy events in writing play workshops with children aged three to five: A study of agential cuts with the artographic triple dimensions as a lens. International Journal of Education and the Arts, 20(3), 127.

Bennett, J. (2010). Vibrant matter: A political ecology of things. England: Duke University Press. https://doi.org/10.1215/9780822391623

Bogost, I. (2012). Alien phenomenology, or what it's like to be a thing. Minneapolis: University of Minnesota Press. https://doi.org/10.5749/minnesota/9780816678976.001.0001

Braidotti, R. (2013). The Posthuman. Cambridge: Polity.

Burman, E. (2016). Deconstructing developmental psychology. London: Routledge. https://doi.org/10.4324/9781315727127

Clark, A., \& Moss, P. (2001). Listening to young children: The mosaic approach. London: National Children's Bureau.

Coole, D., \& Frost, S. (Eds.). (2010). New materialisms: Ontology, agency, and politics. Durham: Duke University Press. https://doi.org/10.1215/9780822392996

Cregan, K., \& Cuthbert, D. (2014). Global childhoods: Issues and debates. London: SAGE. https://doi.org/10.4135/9781473909656

Crescenzi, L., Jewitt, C., \& Price, S. (2014). The role of touch in pre-school children's learning using iPad versus paper interaction. Australian Journal of Language and Literacy, 27(2), 86-95.

Davies, B. (2014). Listening to children, being and becoming. London: Routledge. https://doi.org/10.4324/9781315770390

Deleuze, G. (1997). Desire and pleasure. In A. Davidson (Ed.), Foucault and his interlocutors (pp. 183-192). Chicago: University of Chicago Press.

Deleuze, G., \& Guattari, F. (1987). A thousand plateaus: Capitalism and schizophrenia. Minneapolis: The University of Minnesota Press. 
Dobinson, T., \& Dunworth, K. (2019). Literacy unbound: Multiliterate, multilingual, multimodal (1st ed.). Cham: Springer International Publishing. https://doi.org/10.1007/978-3-030-01255-7

Dolphijn, R., \& van der Tuin, I. (2012). New materialism: Interviews and cartographies. Ann Arbor: Open Humanities Press. https://doi.org/10.3998/ohp.11515701.0001.001

Egan, K., \& Ling, M. (2002). We begin as poets: Conceptual tools and the arts in early childhood. In L. Bresler \& C. M. Thompson (Eds.), The arts in chidren's lives: Context, culture, \& curriculum (pp. 93-100). Boston, MA: Kluwer Academic Press. https://doi.org/10.1007/0-306-47511-1_8

Enriquez, G. (2016). Literacies, learning and the body: Putting theory and research into pedagogical practice. London: Routledge. https://doi.org/10.4324/9781315695631

File, N., Basler Wisneski, D., \& Mueller, J. (2012). Strengthening curriculum in early childhood. In N. File, D. Basler Wisneski, \& J. Mueller (Eds.), Curriculum in early childhood education: Re-examined, rediscovered, renewed (pp. 200-205). New York, NY: Routledge. https://doi.org/10.4324/9780203804360

Gershon, W. (2013). Vibrational affect: Sound theory and practice in qualitative research. Cultural Studies \& Critical Methodologies, 13(4), 257-262. https://doi.org/10.1177/1532708613488067

Hackett, A., \& Rautio, P. (2019). Answering the world: Young children's running and rolling as more-than-human multimodal meaning making. International Journal of Qualitative Studies in Education, 32(8), 1019-1031. https://doi.org/10.1080/09518398.2019.1635282

Hackett, A., \& Somerville, M. (2017). Posthuman literacies: Young children moving in time, place and more-than-human worlds. Journal of Early Literacy Research, 17(3), 374-391. https://doi.org/10.1177/1468798417704031

Haraway, D. (2016). Staying with the trouble: Making kin in the Chthulucene. London: Duke University Press. https://doi.org/10.1515/9780822373780

Hargraves, V. (2019). The posthuman conditions of ethics in early childhood literacy: Order-in(g), be(e)ing literacy. In C. R. Kuby, K. Spector, \& J. J. Thiel (Eds.), Posthumanism and literacy education: Knowing/becoming/doing literacies (1st ed., pp. 187-200). New York: Routledge. https://doi.org/10.4324/9781315106083-20

Harwood, D., \& Collier, D. R. (2017). The matter of the stick: Storying/(re)storying children's literacies in the forest. Journal of Early Childhood Literacy, 17(3), 336-352. https://doi.org/10.1177/1468798417712340

Heider, K. L., \& Renck-Jalongo, M. (Eds.). (2014). Young children and families in the information age: Applications of technology in early childhood. Dordrecht: Springer Netherlands. https://doi.org/10.1007/978-94-017-9184-7

Hill, S. E. (2020). Early literacy: A multimodal process. In O. N. Saracho (Ed.), Handbook of research on the education of young children (4th ed., pp. 113-122). New York: Routledge. https://doi.org/10.4324/9780429442827-8

Iovino, S., \& Oppermann, S. (2012). Introduction: Stories come to matter. In S. Iovino \& S. Oppermann (Eds.), Material ecocriticsm (pp. 1-17). Bloomington, IN: Indiana University Press.

Jenks, C. (2005). Childhood (2nd ed.). New York, NY: Routledge.

Jesson, R., McNaughton, S., \& Wilson, A. (2015). Raising literacy levels using digital learning: A design-based approach in New Zealand. Curriculum Journal, 26(2), 198-223. https://doi.org/10.1080/09585176.2015.1045535

Jewitt, C. (2011). An introduction to multimodality. In C. Jewitt (Ed.), The Routledge handbook of multimodal analysis (pp.14-27). New York: Routledge.

Jokinen, P., \& Murris, K. (2020). Inhuman hands and missing child: Touching a literacy event in a Finnish primary school. Journal of Early Childhood Literacy, 20(1), 44-68. https://doi.org/10.1177/1468798420904115

Jones, L., \& Holmes, R. (2014). Evaluation of the Clore art studio: A continuous swirling line, vibrant colour and humble objects [Unpublished Evaluation]. Manchester Metropolitan University for Manchester City Art Gallery.

Koepke, M. (2015). Towards a pedagogy of moments: Radical pedagogies. Inflexions, 8. Retrieved from http://www.inflexions.org/radicalpedagogy/main.html\#Koepke

Kress, G. (1997). Before writing: Rethinking the paths to literacy. New York: Routledge Press.

Kress, G. (2011). What is a mode?. In C. Jewitt (Ed.), The Routledge handbook of multimodal analysis (pp. 54-67). New York: Routledge.

Kuby, C. R., \& Crawford, S. (2018). Intra-activity of humans and nonhumans in writers' studio: (Re)imagining and (re)defining 'social'. Literacy, 52(1), 20-30. https://doi.org/10.1111/lit.12120

Kuby, C. R., \& Rucker, T. G. (2015). Everyone has a Neil: Possibilities of Literacy desiring in writer's studio. Language Arts, 92(5), 314327.

Kuby, C. R., \& Rucker, T. G. (2020). (Re)thinking children as fully (in)human and literacies as otherwise through (re)etymologizing intervene and inequality. Journal of Early Childhood Literacy, 20(1), 13-43. https://doi.org/10.1177/1468798420904774 
A posthuman perspective on early literacy...

Kuby, C. R., Rucker, T. G., \& Darolia, L. H. (2017). Persistence(ing): Posthuman agency in a writers' studio. Journal of Early Childhood Education, 17(3), 353-373. https://doi.org/10.1177/1468798417712067

Kuby, C. R., Spector, K., \& Thiel, J. (2019). Posthumanism and literacy education: Knowing/becoming/doing literacies. New York: Routledge. https://doi.org/10.4324/9781315106083

Leander, K., \& Boldt, G. (2013). Rereading "a pedagogy of multiliteracies": Bodies, texts, and emergence. Journal of Literacy Research, 45(1), 22-46. https://doi.org/10.1177/1086296X12468587

Leander, K. M., Aziz, S., Botzakis, S., Ehret, C., Landry, D., \& Rowsell, J. (2017). Readings and experiences of multimodality. Literacy Research: Theory, Method, and Practice, 66(1), 95-116. https://doi.org/10.1177/2381336917719247

Lemieux, A., \& Rowsell, J. (2020). "This documentary actually makes Welland look good": Exploring posthumaism in a high school documentary film project. In K. Toohey, S. Symthe, D. Dagenais, \& M. Forte (Eds.), Transforming language and literacy education: New materialism, posthumanism, and ontoethics (pp. 120-135). New York, NY: Routledge. https://doi.org/10.4324/9780429491702$\underline{7}$

Lenz Taguchi, H. (2010). Going beyond the theory/practise divide in early childhood education. London: Routledge. https://doi.org/10.4324/9780203872956

Lenz Taguchi, H. (2013). Images of thinking in feminist materialisms: Ontological divergences and the production of researcher subjectivities. International Journal of Qualitative Studies in Education, 26(6), $706-716$. https://doi.org/10.1080/09518398.2013.788759

Lenz Taguchi, H. (2014). New materialism and play. In L. Brooker, M. Blaise, \& S. Edwards. (Eds.), Sage handbook of play and learning in early childhood (pp. 79-90). London: Sage. https://doi.org/10.4135/9781473907850.n9

MacRae, C., Hackett, A., Holmes, R., \& Jones, L. (2018). Vibrancy, repetition and movement: Posthuman theories for reconceptualising young children in museums. Children's Geographies, 16(5), 503-515. https://doi.org/10.1080/14733285.2017.1409884

Manning, E. (2016). The minor gesture. London: Duke University Press. https://doi.org/10.1515/9780822374411

Massumi, B. (2002). Parables for the virtual: Movement, affect, sensation. Durham: Duke University Press. https://doi.org/10.1215/9780822383574

Murris, K. (2016). The posthuman child: Educational transformation through philosophy with picturebooks. New York: Routledge. https://doi.org/10.4324/9781315718002

Narey, M. J. (2017). Multimodal perspectives of language, literacy, and learning in early childhood: The creative and critical art of making meaning. Cham: Springer. https://doi.org/10.1007/978-3-319-44297-6

Olsson, L. (2009). Practical resources: Preschoolers in Stockholm and its suburbs hwere subjectivity and learning take on the features of a relation field. In Movement and experimentation in young children's learning: Deleuze and Guattari in early childhood education (pp. 11-22). London: Routledge.

Pacini-Ketchabaw, V., Kind, S., \& Kocher, L. M. (2017). Encounters with materials in early childhood education. New York: Routledge. https://doi.org/10.4324/9781315743257

Pahl, K. (2014). Materializing literacies in communities: The uses of literacy revisited. London: Bloomsbury Academic.

Procter, L. (2013). Emotions, power and schooling: The socialisation of 'angry boys'. Journal of Political Power, 6(3), 495-510. https://doi.org/10.1080/2158379X.2013.849370

Procter, L., \& Hackett, A. (2017). Playing with place in early childhood: An analysis of dark emotion and materiality in children's play. Contemporary Issues in Early Childhood, 18(2), 213-226. https://doi.org/10.1177/1463949117714082

Roelvink, G., \& Zolkos, M. (2015). Posthumanist perspectives on affect: Framing the field. Journal of Theoretical Humanities, 20 (3), 1-20. https://doi.org/10.1080/0969725X.2015.1065106

Sanzo, K. (2018, April 25). New materialism(s). Genealogy of the Posthuman. Retrieved from https://criticalposthumanism.net/newmaterialisms/

Savina, E. (2014). Does play promote self-regulation in children? Early Child Development and Care, 184(11), $1692-1705$. https://doi.org/10.1080/03004430.2013.875541

Schulte, C. M. (2019a). The untimely death of a bird: A posthuman tale. In C. R. Kuby, K. Spector, \& J. J. Thiel (Eds.), Posthumanism and literacy education: Knowing/becoming/doing literacies (1st ed., pp. 71-81). New York: Routledge. https://doi.org/10.4324/9781315106083-8

Schulte, C. M. (2019b). Wild encounters: A more-than-human approach to Children's drawing. Studies in Art Education, 60(2), 92-102. https://doi.org/10.1080/00393541.2019.1600223

Shouse, E. (2005). Feeling, emotion, affect. M/C Journal, 8(6). https://doi.org/10.5204/mcj.2443

Sintonen, S. (2020). From an experimental paper to a playful screen: How the essence of materiality modulates the process of creation. 
British Journal of Educational Technology, 51(4), 1322-1333. https://doi.org/10.1111/bjet.12906

Thiel, J. J. (2015). Vibrant matter: The intra-active role of objects in the construction of young children's literacies. Literacy Research: Theory, Method, and Practice, 64(1), 112-131. https://doi.org/10.1177/2381336915617618

Theil, J. J., Kuby, C. R., \& Spector, K. (2019). Agency. In C. R. Kuby, K. Spector, \& J. J. Thiel (Eds.), Posthumanism and literacy education: Knowing/becoming/doing literacies (pp. 19-20). New York, NY: Routledge.

Toohey, K., Dagenais, D., Fodor, A., Hof, L., Nunez, O., \& Singh, A. (2015). "That sounds so cool": Entanglements of children, digital tools, and literacy practices. TESOL, 49(3), 461-485. https://doi.org/10.1002/tesq.236

Wargo, J. M. (2017). Rhythmic rituals and emergent listening: Intra-activity, sonic sounds, and digital composing with young children. Journal of Early Childhood Literacy, 17(3), 392-408. https://doi.org/10.1177/1468798417712573

Wargo, J. M. (2018). Writing with wearables? Young children's intra-active authoring and the sounds of emplaced invention. Journal of Literacy Research, 50(4), 502-523. https://doi.org/10.1177/1086296X18802880

Weheliye, A. (2014). Habeas viscus: Racializing assemblages, biopolitics, and black feminist theories of the human. Durham: Duke University Press. https://doi.org/10.1515/9780822376491

Wohlwend, K. E., Peppler, K. A., Keune, A., \& Thompson, N. (2017). Making sense and nonsense: Comparing mediated discourse and agential realist approaches to materiality in a preschool makerspace. Journal of Early Childhood Literacy, 17(3), 444-462. https://doi.org/10.1177/1468798417712066

You, C. (2019). Representing zoo animals: The other-than-anthropocentric in Anthony Browne's picture books. The Lion and the Unicorn, 43(1), 22-41. https://doi.org/10.1353/uni.2019.0002

Zachariou, A., \& Whitebread, D. (2015). Musical play and self-regulation: Does musical play allow for the emergence of self-regulatory behaviours? International Journal of Play, 4(2), 116-135. https://doi.org/10.1080/21594937.2015.1060572

Žižek, S. (2014). Absolute recoil: Towards a new foundation of dialectical materialism. New York: Verso. 